\title{
Acute Effects of Alinidine on Heart Rate and Blood Pressure in Healthy Subjects and Patients with Hyperkinetic Heart Syndrome
}

\author{
B. Stanek ${ }^{1}$, W. Reiterer ${ }^{2}$, P. Placheta ${ }^{1}$, and G. Raberger ${ }^{1}$ \\ 'Pharmakologisches Institut der Universität Wien and ${ }^{2}$ Allgemeine Poliklinik, Wien, Austria
}

Summary. The effects of a single dose of alinidine $(0.5 \mathrm{mg} / \mathrm{kg}$ i. v. $)$, the $\mathrm{N}$-allyl-derivative of clonidine, on heart rate and blood pressure were investigated in healthy volunteers and in patients with hyperkinetic heart syndrome, at rest and during bicycle exercise. In healthy volunteers plasma catecholamine levels were also determined. Alinidine did not change heart rate at rest in the healthy volunteers but it did significantly reduce exercise-induced tachycardia, whereas blood pressure and plasma catecholamine levels were not significantly affected by alinidine, either at rest or during exercise. In patients with hyperkinetic heart syndrome, alinidine reduced heart rate at rest and during exercise to a similar extent as propranolol $(0.1 \mathrm{mg} / \mathrm{kg}$ i.v.). The blood pressure did not change with alinidine but it was significantly reduced by propranolol. The observation that an alinidine-induced reduction of heart rate occurs without a concomitant fall in blood pressure, and without a clonidine-like symphatho-inhibitory action, is in line with experimental findings suggesting a specific bradycardic action of alinidine under short-term conditions.

Key words: hyperkinetic heart syndrome, alinidine; bradycardia, blood pressure, sympatho-inhibition

Alinidine (ST 567) is a clonidine-like imidazoline derivative (Fig.1). Its most prominent pharmacological action is bradycardia (Kobinger et al. 1979 a, b). Unlike clonidine, whose negative chronotropic effect is considered to be centrally mediated, and is usually associated with a fall in blood pressure, experimental data point towards a direct action of alinidine on the sinus node (Lillie et al. 1979). Preliminary clinical trials have suggested a bradycardic action of alinidine in man, too (Harron et al. 1981; Kaspar et al. 1981). The absence of $\beta$-receptor blocking activity, as well as the observation that bradycardia was not accompanied by a negative inotropic or negative dromotropic effect in low doses, clearly distinguish alinidine from all known bradycardic agents. In conjunction with the bradycardia a decrease in myocardial oxygen demand has been found (Traunecker and Walland 1980). Alinidine appeared, therefore, to be of therapeutic value in the treatment of ischaemic heart disease.

In order to obtain more information about the action of alinidine in man, its acute effects on exercise-induced changes in heart rate, blood pressure and plasma catecholamines were investigated in healthy subjects. And, the acute haemodynamic effects of alinidine and propranolol were compared in patients with hyperkinetic heart syndrome.

\section{Patients and Methods}

Part I of the study was performed at weekly intervals as a randomized, cross-over, double blind trial in 6 healthy males. Physical work consisted of bicycle
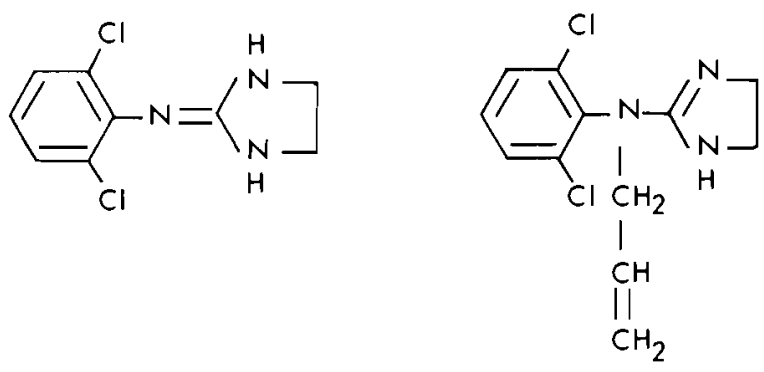

Fig.1. Structure of alinidine (ST 567) 2-N-allyl-N-(2,6-dichlorophenyl)-amino-2-imidazoline (right), and clonidine (left) 


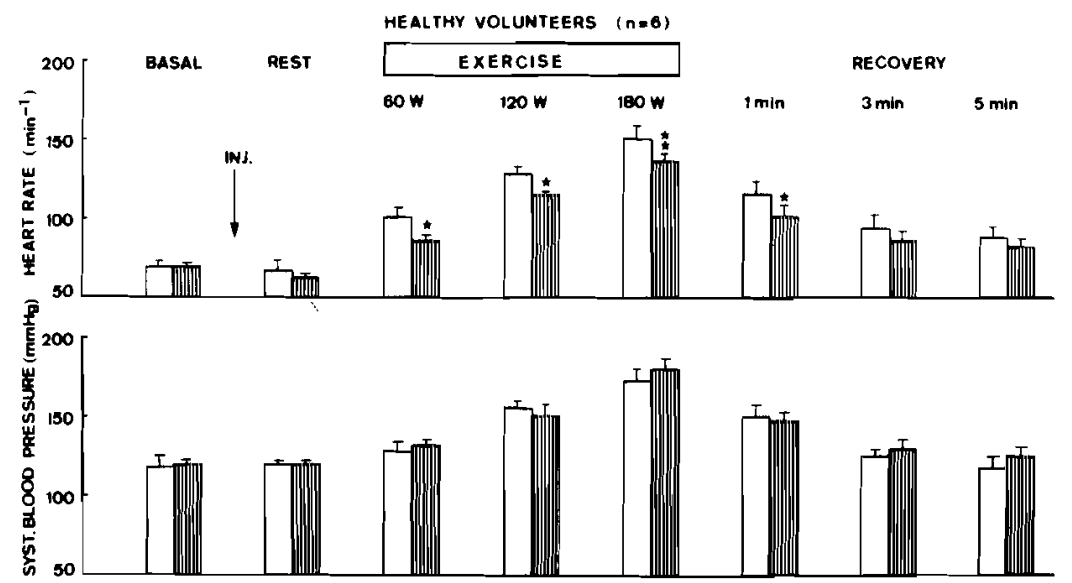

Fig. 2. Effect of a single i.v. injection of alinidine $0.5 \mathrm{mg} / \mathrm{kg}$ on heart rate and systolic blood pressure in 6 healthy volunteers at rest and during exercise

Table 1. Effects of alinidine $0.5 \mathrm{mg} / \mathrm{kg}$ i.v. or placebo (saline i.v.) on individual plasma norepinephrine (NE) levels and heart rate (HR) in 5 healthy volunteers

\begin{tabular}{|c|c|c|c|c|c|c|c|c|c|c|c|c|}
\hline & \multicolumn{6}{|c|}{ Placebo Exercise } & \multicolumn{6}{|c|}{ Alinidine Exercise } \\
\hline & Basal & Rest & $60 \mathrm{~W}$ & $120 \mathrm{~W}$ & $180 \mathrm{~W}$ & Recovery & Basal & Rest & $60 \mathrm{~W}$ & $120 \mathrm{~W}$ & $180 \mathrm{~W}$ & Recovery \\
\hline $\begin{array}{l}1 \mathrm{NE}\left[\mathrm{pg} / \mathrm{ml}^{-}\right] \\
\mathrm{HR}\left[\mathrm{min}^{-1}\right]\end{array}$ & 167 & $\begin{array}{r}141 \\
75\end{array}$ & $\begin{array}{l}284 \\
110\end{array}$ & $\begin{array}{l}278 \\
134\end{array}$ & $\begin{array}{l}436 \\
180\end{array}$ & $\begin{array}{l}284 \\
115\end{array}$ & 125 & $\begin{array}{r}764 \\
64\end{array}$ & $\begin{array}{r}145 \\
77\end{array}$ & $\begin{array}{l}201 \\
124\end{array}$ & $\begin{array}{l}349 \\
155\end{array}$ & $\begin{array}{r}238 \\
98\end{array}$ \\
\hline $\begin{array}{l}2 \mathrm{NE}\left[\mathrm{pg} / \mathrm{ml}^{2}\right] \\
\mathrm{HR}\left[\mathrm{min}^{-1}\right]\end{array}$ & 621 & $\begin{array}{r}437 \\
80\end{array}$ & $\begin{array}{l}568 \\
104\end{array}$ & $\begin{array}{l}602 \\
130\end{array}$ & $\begin{array}{l}626 \\
155\end{array}$ & $\begin{array}{l}284 \\
105\end{array}$ & 408 & $\begin{array}{r}364 \\
70\end{array}$ & $\begin{array}{r}418 \\
90\end{array}$ & $\begin{array}{l}557 \\
116\end{array}$ & $\begin{array}{l}618 \\
140\end{array}$ & $\begin{array}{r}268 \\
93\end{array}$ \\
\hline $\begin{array}{l}3 \mathrm{NE}[\mathrm{pg} / \mathrm{ml}] \\
\operatorname{HR}\left[\mathrm{min}^{-1}\right]\end{array}$ & 332 & $\begin{array}{r}351 \\
66\end{array}$ & $\begin{array}{l}338 \\
112\end{array}$ & $\begin{array}{l}437 \\
142\end{array}$ & $\begin{array}{l}656 \\
155\end{array}$ & $\begin{array}{r}235 \\
98\end{array}$ & 491 & $\begin{array}{r}332 \\
55\end{array}$ & $\begin{array}{r}492 \\
93\end{array}$ & $\begin{array}{l}569 \\
113\end{array}$ & $\begin{array}{l}604 \\
138\end{array}$ & $\begin{array}{r}265 \\
86\end{array}$ \\
\hline $\begin{array}{l}4 \mathrm{NE}[\mathrm{pg} / \mathrm{ml}] \\
\operatorname{HR}\left[\mathrm{min}^{-1}\right]\end{array}$ & 189 & $\begin{array}{r}195 \\
46\end{array}$ & $\begin{array}{r}220 \\
84\end{array}$ & $\begin{array}{l}356 \\
112\end{array}$ & $\begin{array}{l}577 \\
131\end{array}$ & $\begin{array}{r}282 \\
54\end{array}$ & 273 & $\begin{array}{r}297 \\
60\end{array}$ & $\begin{array}{r}2141 \\
81\end{array}$ & $\begin{array}{r}2386 \\
113\end{array}$ & $\begin{array}{l}680 \\
127\end{array}$ & $\begin{array}{r}303 \\
71\end{array}$ \\
\hline $\begin{array}{l}5 \mathrm{NE}[\mathrm{pg} / \mathrm{ml}] \\
\text { HR }\left[\mathrm{min}^{-1}\right]\end{array}$ & 140 & $\begin{array}{r}165 \\
52\end{array}$ & $\begin{array}{r}150 \\
90\end{array}$ & $\begin{array}{l}166 \\
109\end{array}$ & $\begin{array}{l}253 \\
136\end{array}$ & $\begin{array}{r}143 \\
86\end{array}$ & 230 & $\begin{array}{r}286 \\
64\end{array}$ & $\begin{array}{r}2872 \\
87\end{array}$ & $\begin{array}{l}266 \\
108\end{array}$ & $\begin{array}{l}432 \\
122\end{array}$ & $\begin{array}{r}175 \\
76\end{array}$ \\
\hline $\begin{array}{ll}n=5 & \mathrm{NE}[\mathrm{pg} / \mathrm{ml}] \\
& \text { mean } \pm \mathrm{SEM}\end{array}$ & $\begin{array}{r}289,8 \\
\pm 89,2\end{array}$ & $\begin{array}{r}257,8 \\
\pm 57,9\end{array}$ & & & $\begin{array}{r}509,6 \\
\pm 74,4\end{array}$ & $\begin{array}{r}245,6 \\
\pm 27,3\end{array}$ & $\begin{array}{r}305,4 \\
\pm 64,9\end{array}$ & $\begin{array}{r}408,6 \\
\pm 89,9\end{array}$ & & & $\begin{array}{r}536,6 \\
\pm 58,8\end{array}$ & $\begin{array}{r}249,8 \\
\pm 21,3\end{array}$ \\
\hline
\end{tabular}

exercise in the supine position. In a pre-test maximal work load was determined by means of non-steadystate continuous exercise (Reiterer 1976), and was found to be similar in all 6 volunteers at $237.5 \pm 5.6$ (mean \pm SEM, W). The work load used in the exercise test was 60,120 and $180 \mathrm{~W}$, which was $25 \%, 51 \%$ and $76 \%$ of the maximal work load, respectively. Each work load period lasted for $3 \mathrm{~min}$.

A Venflon ${ }^{\circledR}$ catheter was inserted into the left antecubital vein, and after $45 \mathrm{~min}$ rest in the supine position, blood samples were taken for determination of basal catecholamine levels. Then, alinidine $0.5 \mathrm{mg} / \mathrm{kg}$ or an equivalent volume of saline was injected.

Fifteen min after injection the exercise test was started. Blood samples for the determination of catecholamines were taken immediately prior to work
(= REST), during the third min of each work load

(= EXERCISE) and $5 \mathrm{~min}$ after the end of exercise (= RECOVERY). Heart rate was derived from the ECG, systolic blood pressure was measured by cuff method. Plasma catecholamines were determined by a radioenzymatic method (Da Prada and Zürcher 1976).

Part II of the study was a comparison of the action of alinidine and propranolol in 8 patients with hyperkinetic heart syndrome, whose heart rate exceeded 110 beats/min when exercising at a zero $\mathrm{W}$ load. Maximal work load in these patients was determined in a pre-test as described above, and was about $86 \%$ of that of age-matched control subjects. The study was performed on different test days (weekly intervals) in a random order. Saline, alinidine $(0.5 \mathrm{mg} / \mathrm{kg}$ 

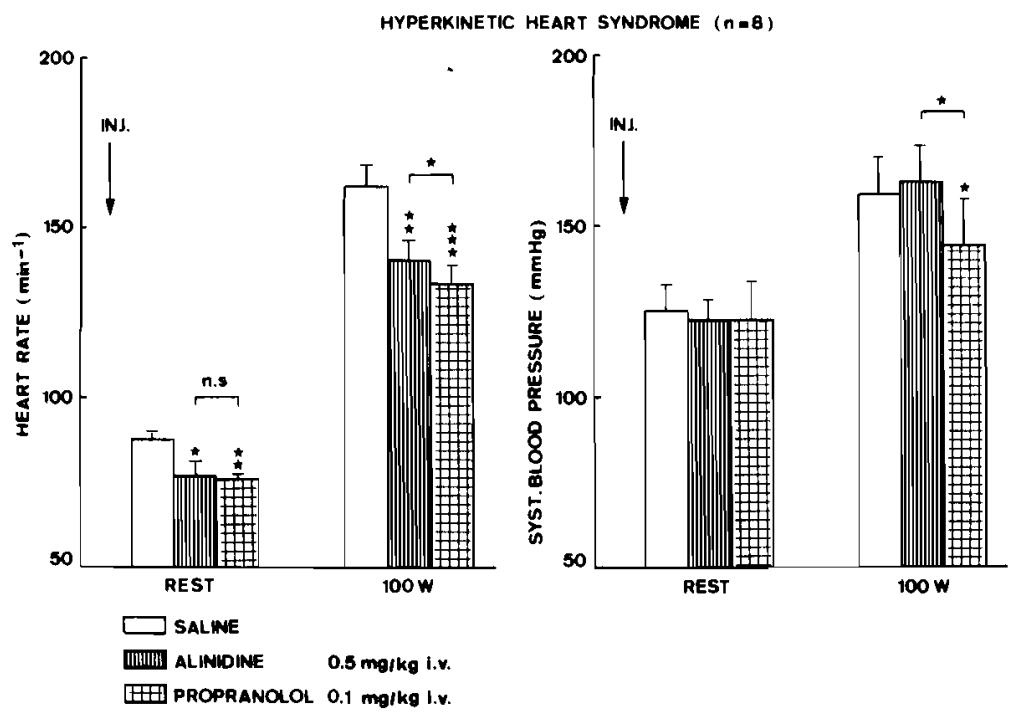

Fig. 3. Effects of a single i.v. injection of alinidine $0.5 \mathrm{mg} / \mathrm{kg}$ or propranolol $0.1 \mathrm{mg} / \mathrm{kg}$ on heart rate and systolic blood pressure in 8 patients with hyperkinetic heart syndrome at rest and during exercise i.v.) or propranolol $(0.1 \mathrm{mg} / \mathrm{kg}$ i.v. $)$ were injected 10 min prior to the exercise test, which was performed at up to a $100 \mathrm{~W}$ load.

Statistical analysis used Student's $t$-test for paired data. Values are recorded as mean \pm SEM.

For both studies written consent was given by each subject after complete explanation of the protocol and provison of information about possible risks.

\section{Results}

\section{Part I: Healthy Volunteers}

Effect of Alinidine $(0.5 \mathrm{mg} / \mathrm{kg}$ i.v.) on Heart Rate and Systolic Blood Pressure (Fig. 2). Heart rate and systolic blood pressure at rest remained unchanged $15 \mathrm{~min}$ after the injection of alinidine. Alinidine did not significantly alter the rise in systolic blood pressure during exercise, whereas the exercise-induced increase in heart rate was significantly reduced by alinidine at each work load tested. This effect was not observed after 3 and $5 \mathrm{~min}$ of recovery.

Effect of Alinidine $(0.5 \mathrm{mg} / \mathrm{kg}$ i.v.) on Plasma Norepinephrine (NE) Levels (Table 1). Plasma NE levels were determined in 5 subjects. Basal values of plasma NE were similar in the placebo and alinidine groups. Alinidine had no influence on plasma NE levels at rest.

With the first stage of exercise a marked increase in plasma NE was present in 2 of 5 subjects, which persisted in 1 during the next stage. Both subjects had normal basal NE levels and their plasma NE returned to levels comparable to the other subjects tested when exercise was continued at a $180 \mathrm{~W}$ load. Interestingly, both subjects had low pre-treatment heart rates and showed only minor changes in heart rate with alinidine when exercising at 60 and $120 \mathrm{~W}$ loads, respectively.

With submaximal exercise, the increases in plasma NE were not influenced by alinidine in any of the 5 subjects, nor were the decreases in plasma NE during recovery.

\section{Part II: Patients with Hyperkinetic Heart Syndrome}

Effect of Alinidine $(0.5 \mathrm{mg} / \mathrm{kg}$ i.v.) or Propranolol $(0.1 \mathrm{mg} / \mathrm{kg}$ i.v.) on Heart Rate and Systolic Blood Pressure (Fig. 3). In these patients, injection either of alinidine or propranolol significantly reduced resting heart rate by $10.0 \pm 4.5$ and $11.0 \pm 3.0$ beats $/ \mathrm{min}$, respectively, whereas resting systolic blood pressure remained unchanged. Alinidine reduced exercise-induced tachycardia by $22 \pm 4.6$ beats $/ \mathrm{min}$, which was comparable to the reduction achieved by propranolol $(28 \pm 4.8$ beats $/ \mathrm{min})$. The exercise-induced increase in systolic blood pressure, was significantly reduced by propranolol but remained unchanged after alinidine.

\section{Discussion}

The bradycardic action of alinidine appears to depend on the pre-existing heart rate. Thus, alinidine $(0.5 \mathrm{mg} / \mathrm{kg}$ i. v. $)$ reduced exercise-induced tachycardia, but had no influence on resting heart rate in healthy subjects. In patients with hyperkinetic heart syndrome, alinidine reduced both resting heart rate and exercise-induced tachycardia. Similar effects of alinidine have been observed during sodium nitroprusside-induced reflex tachycardia in man (Zimpfer 
et al. 1982), as well as in conscious dogs (Kobinger et al. $1979 \mathrm{a}, \mathrm{b})$.

The chemical relationship between alinidine and clonidine raises the question of a clonidine-like central cardiovascular action of alinidine, namely sympatho-inhibition. Basal catecholamine levels, which were in the range quoted in the literature (Lake et al. 1976), were not suppressed by alinidine in the present study, whereas catecholamine levels were found to be markedly reduced after a single oral dose of clonidine (Metz et al. 1978). The exercise-induced increase in plasma catecholamines under placebo conditions was comparable to that in previous studies (Christensen and Brandsborg 1973; Hansson and Hökfelt 1975). The same increase was observed with alinidine, indicating that it had no effect on exerciseinduced reflex stimulation of the sympathetic nervous system.

Part II of the present study was performed in order to differentiate the haemodynamic effects of alinidine and a $\beta$-receptor antagonist, propranolol. At the dosages used, both alinidine and propranolol reduced exercise-induced tachycardia to a similar extent. However, there was a differential effect on the exercise-induced increase in systolic blood pressure, suggesting that the action of alinidine is not mediated by $\beta$-receptor blockade. Similar conclusions were drawn by Harron et al. (1981), who showed that alinidine attenuated exercise-induced tachycardia in healthy subjects but had no influence on isoprenaline tachycardia.

The present results support the concept that the acute bradycardic action of alinidine in man is due neither to clonidine-like central sympatho-inhibition nor to $\beta$-receptor blockade.

Acknowledgements. We are grateful to Prof. Hornykiewicz for providing laboratory facilities for the performance of catecholamine assays, and to Mrs. E. Kotai and M.Scherer for expert technical assistance.

\section{References}

1. Christensen NJ, Brandsborg O (1973) The relationship between plasma catecholamine concentration and pulse rate during exercise and standing. Eur J Clin Invest 3: 299-306
2. Da Prada M, Zürcher G (1976) Simultaneous radioenzymatic determination of plasma and tissue adrenaline, noradrenaline and dopamine within the femtomole range. Life Sci 19: 1161-1174

3. Haber E, Körner T, Page LB, Kliman B, Purnode A (1969) Application of a radioimmunoassay for angiotensin $I$ to the physiologic measurement of plasma renin activity in normal human subjects. J Clin Endocrinol Metab 29: 1349-1355

4. Hansson BG, Hökfelt (1975) Long term treatment of moderate hypertension with penbutolol (Hoe 893 d). I. Effects on blood pressure, pulse rate, catecholamines in blood and urine, plasma renin activity and urinary aldosterone under basal conditions and following exercise. Eur J Clin Pharmacol 9:9-19

5. Harron DWG, Riddell JG, Shanks RG (1981) Alinidine reduces heart-rate without blockade of beta-adrenoceptors. Lancet 1:351-353

6. Kaspar W, Meinertz T, Treese N, Kerstin F, Pop T, Jähnchen E (1981) Clinical electrophysiological properties of $\mathrm{N}$-allylclonidine (ST 567) in man. J Cardiovasc Pharmacol 3: 39-47

7. Kobinger W, Lillie C, Pichler L (1979 a) N-allyl-derivative of clonidine, a substance with specific bradycardic action at a cardiac site. Naunyn-Schmiedebergs Arch Pharmacol 306: 255-262

8. Kobinger W, Lillie C, Pichler L (1979b) Cardiovascular action of N-allyl-clonidine (ST 567), a substance with specific bradycardic action. Eur J Pharmacol 58: 141-150

9. Lake CR, Ziegler MG, Kopin IJ (1976) Use of plasma norepinephrine for evaluation of sympathetic neuronal function in man. Life Sci 18: 1315-1326

10. Lillie C, Kobinger W, Pichler L (1979) ST 567, 2-N-allyl-N(2,6-dichlorophenyl)-2-imidazoline, a specific bradycardic agent. Naunyn-Schmiedebergs Arch Pharmacol 307: R40

11. Metz SA, Halter JB, Porte D Jr, Robertson RP (1978) Suppression of plasma catecholamines and flushing by clonidine in man. J Clin Endocrinol Metab 46: 83-90

12. Reiterer W (1976) Evaluation of physical performance by rectangular-triangular bicycle ergometry and computer-assisted ergospirometry. Basic Res Cardiol 71: 482-487

13. Traunecker W, Walland A (1980) Haemodynamic and electrophysiologic actions of alinidine in the dog. Arch Int Pharmacodyn Ther 244: 58-72

14. Zimpfer M, Fitzal S, Semsroth M (1982) Relative roles of heart rate and ventricular stroke volume for the regulation of cardiac output during controlled hypotension with sodium nitroprusside in man. Eur J Clin Invest 12:9-13

Received: January 7, 1982

accepted in revised form: July 23,1982

Dr. B. Stanek

Pharmakologisches Institut der

Universität Wien

Währingerstrasse 13 a

A-1090 Wien, Austria 